\title{
The Coreoidea Leach, 1815 \\ (Hemiptera: Heteroptera) of Magallanes Region: Checklist and identification key to the species
}

\author{
Los Coreoidea Leach, 1815 (Hemiptera: Heteroptera) \\ de la Región de Magallanes: Lista de especies y clave de identificación
}

Eduardo I. Faúndez ${ }^{1,2}$

\begin{abstract}
Members of the Coreoidea of Magallanes Region are listed. First records in the Magallanes Region are provided for Harmostes (Neoharmostes) procerus Berg, 1878 and Althos nigropunctatus (Signoret, 1864). It is concluded that three species classified in three genera and two families are present in the region. A key to the species is provided.
\end{abstract}

Key words: Coreidae, Rhopalidae, Distribution, New records, Chile.

\section{Resumen}

Se listan los Coreoidea de la Region de Magallanes. Se entregan los primeros registros para la región de Harmostes (Neoharmostes) procerus Berg, 1878 y Althos nigropunctatus (Signoret, 1864). Se concluye que en Magallanes habitan tres especies de esta superfamilia clasificadas en tres géneros y dos familias. Se entrega una clave para la identificación de estas especies.

Palabras clave: Coreidae, Rhopalidae, Distribución, Nuevos registros, Chile.

\section{INTRODUCTION}

The Coreoidea is a large superfamily of Pentatomomorphans currently composed of the families Alydidiae, Coreidae, Hyocephalidae, Rhopalidae, Stenocephalidae and the fossil Trisegmentatidae. The Coreoidea is estimated to contain 3099 valid species (Livermore et al. 2016). Coreoids are primarly phytophages (Schuh \&
Slater, 1995), and several species are economically important; there are, however, also cases in which species of this superfamily have been recorded feeding on carrion and dung (Mitchell, 2000). Additionally, biting humans has been recorded in members of this group (Faúndez \& Carvajal, 2011). In Chile, the Coreoidea is represented by two families, the Coreidae and Rhopalidae, and the major diversity for this group is found in the central zone of the country (Faúndez, 2015b).

In Magallanes, very little is known about the species of this superfamily, and actually there is only one species officially recorded from the area: the dunes bug, Eldarca nigroscutellata Faúndez, 2015 (Coreidae). The purpose of this contribution is to provide an update of this group in the Magallanes Region, as well as to provide a tool for the identification of the species.

\section{MATERIALS AND METHODS}

A compilation of literature was made together with the examination of material from the following collections: Heteroptera Reference Collection of the CEBCh (HRCC), Instituto de la Patagonia, Universidad de Magallanes (IPUM) and Wladimir Cekalovic

1 Entomology Department, School of Natural Resource Sciences, North Dakota State University, Dept. 7650, P.O. Box 6050; Fargo, ND, USA

$\sum$ ed.faundez@gmail.com

2 Departamento de Zoología Médica, Centro de Estudios en Biodiversidad (CEBCh), Magallanes, 1979, Osorno, Chile. 
(WCPC). Photos were taken with a digital camera adapted to a stereoscopic microscope. Terminology for the key follows those in Faúndez (2015a).

\section{RESULTS}

Checklist of the Coreoidea of Magallanes Region

Coreoidea Leach, 1815

Rhopalidae Amyot \& Serville, 1843

Genus Harmostes Burmeister, 1835

Type species: Harmostes dorsalis Burmeister, by monotypy.

Subgenus Neoharmostes Göllner-Scheiding, 1978 Type species: Harmostes procerus Berg, by subsequent designation (Göllner-Scheiding, 1982)

Harmostes (Neoharmostes) procerus Berg, 1878 (Figs. 1, 7)

Material examined: Chile, Magallanes, Última Esperanza Province, Parque Nacional Torres del Paine, 3-II-1987, leg. J. Petersen, $1 \lesssim$ [IPUM]; Chile, Magallanes, Magallanes Province, Cabo Negro, 11-II-1994, leg. V. Pérez, 1ठ [HRCC].

Remarks: This species has not been formally recorded before in Magallanes Region; however Berg (1895, 1896), Breddin (1897) Pall \& Coscaron (2012) and Melo \& Montemayor (2016) recorded it from the Argentinean portion Tierra del Fuego. Therefore, $H$. procerus should be present in the Chilean portion of Tierra del Fuego Island, but more collecting is needed to confirm its presence. This is the southernmost distributed species of the Coreoidea in South America.

Coreidae Leach, 1815

Genus Althos Kirkaldy, 1904

Type species: Margus pectoralis Dallas, inherited from replaced name.

Althos nigropunctatus (Signoret, 1864)

(Figs. 2, 4, 5, 6)

[=Margus nigropunctatus Signoret]

Material examined: Magallanes Region,
Última Esperanza Province, Parque Nacional Torres del Paine, 07-I-1994, leg. J. Acevedo, 2ð 1 ㅇ [HRCC].

Remarks: This is the first record of this species from the Magallanes Region, and it is also the southernmost record known for this genus and species. Althos nigropunctatus has previously been recorded from the Nuble Province in the Bio Bio Region as its southernmost locality (Brailovsky, 1991). This new record greatly extends the known distribution of this species to the south. The examination male genitalia (i.e. the entire posteroventral border of the pygophore and the shape of the paramere, Figs. 4 and 6) and the female terminalia (Fig. 5) confirm the identity of this species. This species is probably widely distributed in southern Chile but further collecting is needed.

Genus Eldarca Signoret, 1864

Type species: Merocoris haematomerus Spinola, subsequent designation by Packauskas, 2010 (see note below).

Remark: Signoret (1864) did not designate a type species for this genus. Packauskas (2010), in his catalog of the New World Coreidae, indicated that Merocoris haematomerus (actually Eldarca haematomera haematomera) was the type species without justification or comment. Later, Faúndez (2015a), in the synopsis of Eldarca, accepted this designation without further comment. Therefore, Merocoris haematomerus should be accepted as the type species of the genus Eldarca by subsequent designation (Packauskas, 2010).

(Fig. 3)

Eldarca nigroscutellata Faúndez, 2015

Material examined: Chile, Magallanes Region, Última Esperanza Province, $4 \mathrm{~km}$ south of Cerro Guido, 9-I-2007, leg. T. \& W. Cekalovic 1 ㅇ [WCPC].

Remarks: This species is endemic to Patagonia, and is the southernmost distributed Coreidae in South America. In addition to the record here given here, it has also been recorded from the Magallanes Region from Pali-Aike (Magallanes Province) and Torres del Paine (Última Esperanza Province) National Parks (Faúndez, 2015). 
Key to the species of Coreoidea from the Magallanes Region

1(2) Metathoracic scent glands obsolete, metafemora with several spines (Fig. 7)

Harmostes procerus Berg

2 (1) Methathoracic scent glands well developed, metafemora unarmed

3

3 (4) Connexiva and lateral margins of pronotum distinctly ivory, general coloration blackish-blue (Fig. 3)

Eldarca nigroscutellata Faúndez 4 (3) Connexiva and lateral margins of pronotum concolorous with the rest of the dorsum, general coloration greenish-brown (Fig. 2)

Althos nigropunctatus (Signoret)

\section{CONCLUSIONS}

Coreoidea is represented in Magallanes by three species classified in three genera and two families. The highest diversity for this group is found in the Última Esperanza Province with all three species recorded there. The records of $H$. procerus and $A$. nigropunctatus are new additions to Magallanic fauna, increasing the diversity of this group in the Region. The scarce availability of Coreoid records in Magallanes emphasizes the need for more collecting. In addition, further collecting

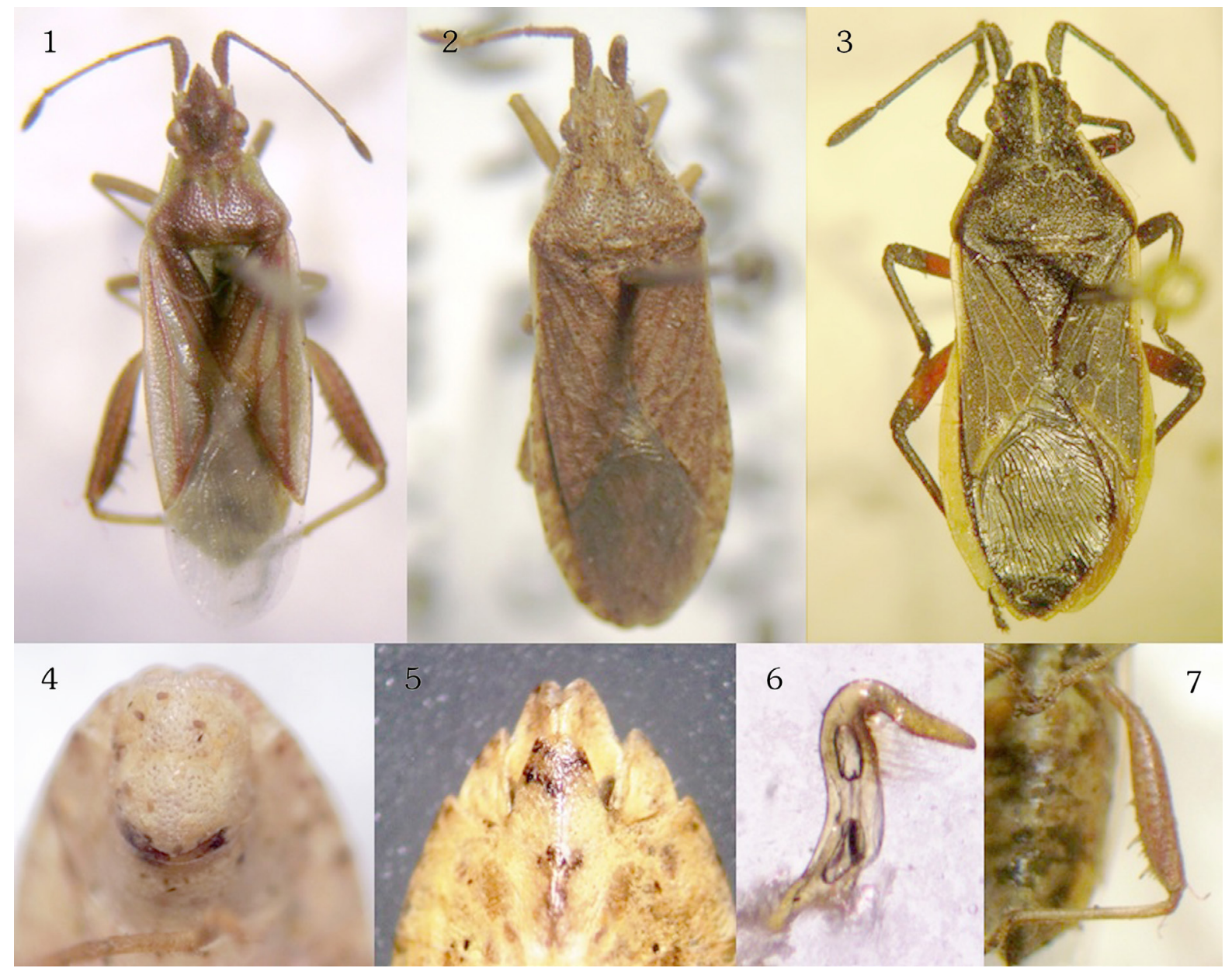

Fig. 1. Harmostes procerus, habitus; Fig. 2. Althos nigropunctatus, habitus; Fig. 3. Eldarca nigroscutellata, habitus; Fig. 4. A. nigropunctatus, male pygophore, ventral view; Fig. 5. A. nigropunctatus, female terminalia, ventral view; Fig. 6. A. nigropunctatus, male right paramere; Fig. 7. H. procerus, spines on metafemur. 
will help elucidate several unknown aspects of the biology (i.e. host plants, immature stages, reproduction) of these species in Magallanes.

\section{ACKNOWLEDGEMENTS}

I thank Harry Brailovsky, for kindly answering my questions; Vicente Perez and Wladimir Cekalovic for collecting some of the specimens used in this work, and David A. Rider for making a critic reading to a previous version of the manuscript.

\section{LITERATURE CITED}

Berg, C. (1895). Hemípteros de la Tierra del Fuego coleccionados por el Señor Backhausen. Anales del Museo Nacional de Buenos Aires, 4, 195-206.

Berg, C. (1896). Contribución al estudio de los Hemípteros de la Tierra del Fuego. Anales del Museo Nacional de Buenos Aires, 5, 131-137.

Brailovsky, H. (1990). Revisión del complejo "Althos" (Hemiptera-Heteroptera-Coreidae). Publicaciones Especiales del Instituto de Biología, Universidad Nacional Autónoma de México, 5, 1-156.

Breddin, G. (1897). Hemipteren. In Hamburger Megalaensischen Sammelreise. Zweite Lieferung, No. 4. Hamburg. $36+2$ pp., 1 pl.

Faúndez, E. I., \& Carvajal, M. A. (2011). Primer registro de una picadura de Leptoglossus chilensis (Spinola, 1852) (Hemíptera: Heteroptera: Coreidae) en un ser humano. Boletín de Biodiversidad de Chile, 6, 2225.

Faúndez, E. I. (2015a). Synopsis of the genus Eldarca Signoret, 1864 (Hemiptera:
Heteroptera: Coreidae). Zootaxa, 3915(2), 287-294.

Faúndez, E. I. (2015b). Primer registro de Vazquezitocoris putrenus Brailovsky \& Barrera, 2012 (Heteroptera: Coreidae) para la Región de Tarapacá (Chile). Idesia, 33(4), 125-127.

Göllner-Scheiding, U. (1982). Ergänzungen zu Gattungen der Rhopalidae (Heteroptera). Deutsche Entomologische Zeitschrift, N.F. 29(4-5), 459-467

Livermore, L. J. R., Lemaître, V. A., Dolling, W. R., \& Webb, M. D. (2016). Coreoidea Species File Online. Version 5.0/5.0. [01/12/2016].

http://Coreoidea.SpeciesFile.org.

Melo, M. C., \& Montemayor, S. I. (2016). Biodiversity of the scentless plant bugs (Hemiptera: Rhopalidae) in southern South America. Journal of Natural History, 50(34), 163-200.

Mitchell, P. L. (2000). Leaf-footed bugs (Coreidae). In C. W. Schaefer \& A. R. Panizzi A. R. (Eds.), Heteroptera of Economic Importance (pp. 337-403). CRC Press, Boca Raton.

Packauskas, R. (2010). Catalog of the Coreidae, or Leaf-Footed Bugs, of the New World. Fort Hays Studies, 4(5), 1-270.

Pall, J. L., \& Coscaron, M. C. (2012). The Rhopalidae (Hemiptera: Heteroptera) of Argentina. Journal of Natural History, 46(23-24), 1441-1465.

Schuh, R. T., \& Slater, J. A. (1995). True bugs of the World (Hemiptera: Heteroptera): Classification and Natural History. Cornell University Press, Ithaca, New York, $336 \mathrm{pp}$.

Signoret, V. (1864). Révision des Hémiptères du Chili. Annales de la Société Entomologique de France, Série 4, 3[1863], 541-588. 